DOI https://doi.org/10.15407/usim.2020.04.056

UDC 681.3 / 621.74 / 339.97

V.S. DOROSHENKO, Doctor (Eng.), Senior Research Associate,

Physical-technological Institute of Metals and Alloys

of the National Academy of Science of Ukraine,

Kyiv, 03680, Vernadskogo Boulevard, 34/1, Ukraine,

doro55v@gmail.com

O.V. TOKOVA, Junior Researcher,

International Research and Training Centre

for Information Technologies and Systems of the NAS of Ukraine,

Glushkov ave., 40, Kyiv, 03187 , Ukraine,

len327@ukr.net

\title{
THE DIGITAL TWIY AND OPTIMIZATION OF CAST METAL STRUCTURES IY ADDITIVE MANUFACTURING
}

\begin{abstract}
A review of a number of sources of information shows that among the advanced technologies CD is an integrator of almost all "endto-end" digital technologies, acts as a driver, provides the prerequisites for development and allows companies and entire industries to move to sustainable development. CD technology has great prospects because it is necessary not only for the creation and operation of a modern "smart" product, but also for its regular maintenance, updating and constant adaptation to new requirements and conditions with the transfer of accumulated data and methods to create new machines, structures and materials.
\end{abstract}

Keywords: metal casting, design optimization, digital duplicate, additive production, 3D printing, digital model, topological optimization, bionic design.

\section{Introduction}

The urgent task of engineering science should be to promote the technological development of the national economy, modernization of its material and technical base with advanced development of the processing industry on the basis of its innovative and technological renewal, development of new products with a higher share of added value. One of the modern technological trends is the "digitalization" of production processes. Its features will be considered in this article based on the examples of obtaining cast metal structures by additive methods.
The term "digital twin" (DT) has become very popular recently. It is used in numerous publications and speeches. It is based on a number of evolving technologies, in particular, on combining information technology with operational processes to create a DT. It is also grounded on the development of concepts of "digital production" and industrial "Internet of Things" (IoT). Extensive monograph [1] is devoted to the expansion of the use of DT in various industries and applications as the mathematical models development, improving in the description of physical processes, as well as in the reflection of complex economic and social phenomena. Based on [1] the methods of DT for 
optimization of cast metal structures in additive production will be considered in continuation of the topic of the article [2].

A number of opportunities that the DT open up in terms of optimizing the properties of the designed structures have not been implemented until recently, primarily due to the fact that not all optimized structures could be fabricated by traditional (subtractive) technologies. According to those traditional technologies the integral blank is brought into a given shape by removing part of the material, for example, using lathes, milling and other machines. Possibilities of topological optimization existed before, but, after the project reached the technologists, it turned out that it is simply impossible to make a structure of the optimal type on the existing fleet of equipment.

\section{Additive Development}

The traditional engineering school designed parts and assemblies from the experience and knowledge of the technological capabilities of equipment for subtractive processing methods. Therefore, it imposed restrictions on the shape of the final structure. In principle, for topological optimization, it is possible to change the traditional geometry to a geometry specially adapted to a certain technology, including the casting and additive process. But it is additive technologies that make the process of topological optimization the most efficient. With the spread of additive technologies, the situation has changed. Nowadays it is possible to produce a structure of almost any shape.

The history of the development of additive manufacturing goes back up to 40 years, but the opportunity to replace critical parts in mechanical engineering with parts manufactured by additive methods has appeared relatively recently. The first 3D printers based on laser stereolithography technology (laser curing of liquid photopolymers) appeared in the late 1980s last century. Fusion printing of microdroplets of molten thermoplastic entered the market ten years later, around 1990. Somewhat later, methods of $3 \mathrm{D}$ printing with metals appeared, examples of which are shown in articles [3, 4]. Selective Laser Melting (SLM) techno- logy was first developed in 1995 at the Fraunhofer Institute of Laser Technologies (ILT) in Aachen (Germany).

Today there are a number of similar technologies: Selective Laser Sintering (SLS), Direct Metal Laser Sintering (DMLS), Selective Laser Melting (SLM), Direct Energy Deposition (DED), Laser Metal Deposition (LMD), and Metal Binder Jetting (MBJ). In fact, they resemble a small melting bath moving along the surface of the growing layers with the constant addition of a metal charge to it. However, in order to solve a complex of problems of physical chemistry, physical metallurgy, peculiarities of the structure formation of additive metal growth, time and new solutions were needed, as noted below.

\section{Topological Optimization}

Today, the cost of 3D printing is falling, and its quality is increasing. Nowadays there are examples of the use of technology even in highly responsible structures [1]. The possibility of redesigning, including cast billets [3-6], using topological optimization allows you to numerically determine the best distribution of metal in a particular structure under known types of loading. The designer establishes the requirements for the required stiffness and strength, minimization of stress concentrators that affect the durability of the structure. On the basis of these parameters the computer calculates the shape of the part, where all these factors would be taken into account.

Today on the market there are a number of software products for topological optimization [1]. This feature is provided by CAD/CAE packages from Siemens, Dassault Systemes and Autodesk. Among the inexpensive solutions, one can single out the Inspire topological and topographic optimization product of the American company solidThinking, a member of the Altair Group. The program allows you to find the optimal design of various structures in terms of mass, stiffness and strength. Manufacturers of products for parametric optimization (Heeds, P7, IOSO, ANSYS Design Explorer) were engaged in such systems production, but outside PLM platforms, apart from the 

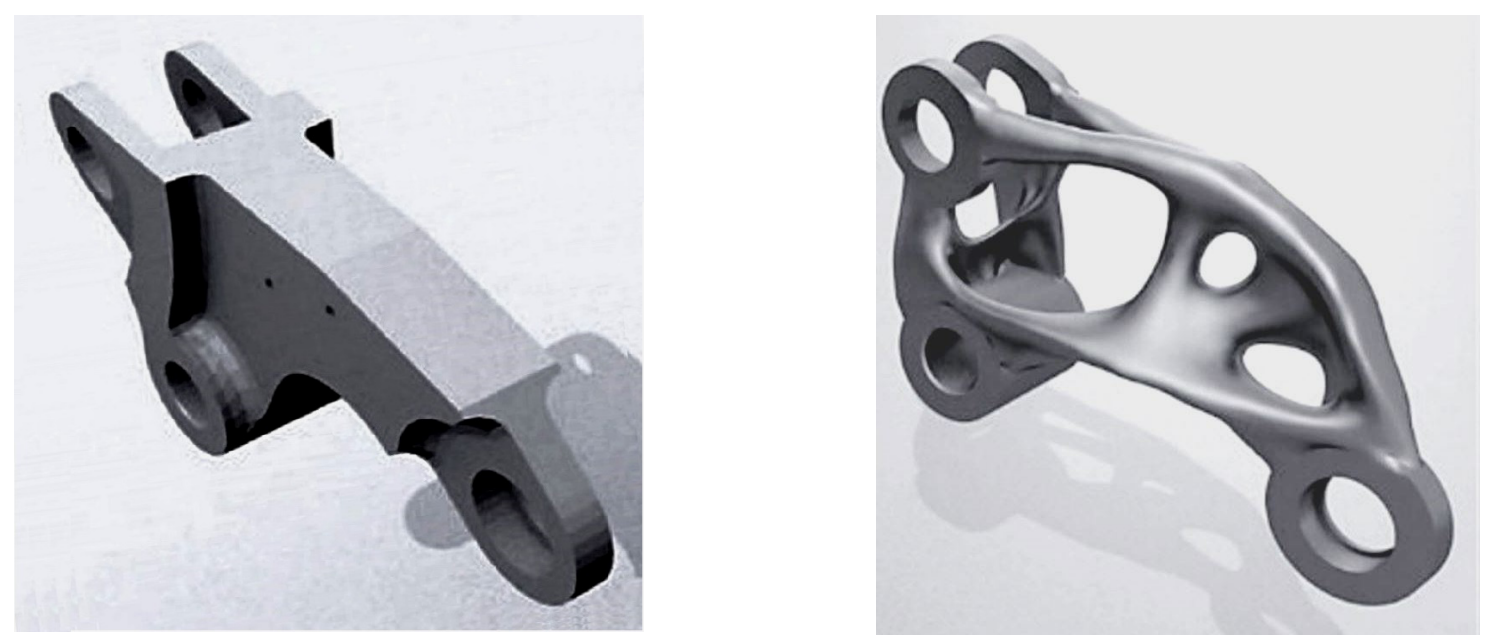

Fig. 1. Comparison of the design of the parts optimized for traditional metalworking and additive manufacturing [7]
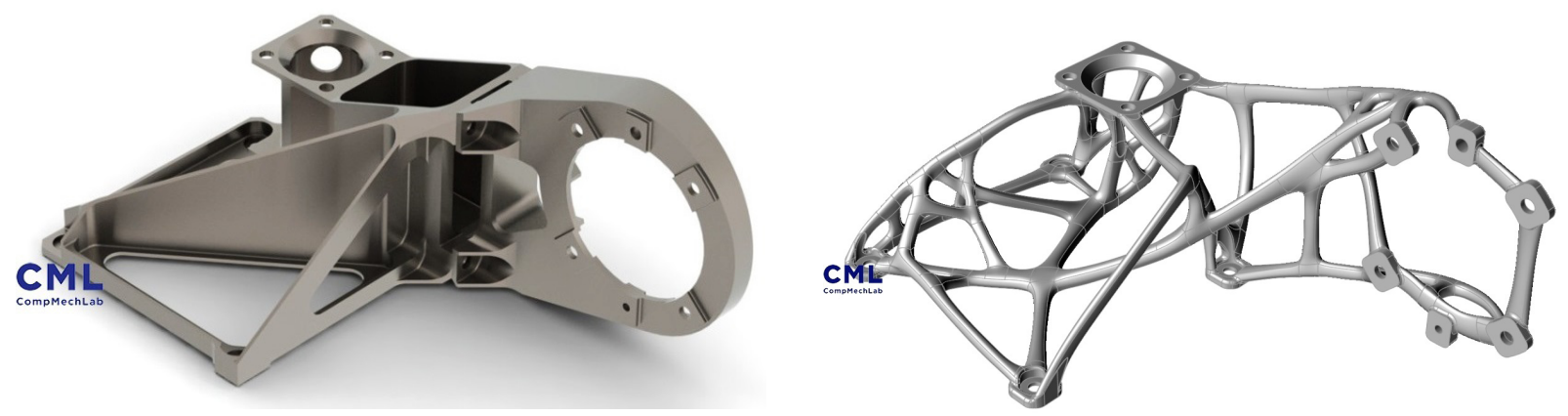

Fig.2. Comparison of the shape of the reflector design, optimized for traditional metalworking and additive manufacturing [8]

DT, their effectiveness is very limited. Methods of multicriteria optimization have also been developed. Within this optimization the number of optimization parameters, in addition to technical ones, also includes cost indicators. This approach allows developers to obtain a variety of products from which to choose potentially competitive. For example, it is possible to simultaneously launch on the market an expensive product with high technical parameters and a cheap one with more modest characteristics.

\section{Examples of Topological Optimization Use}

Fig. 1 shows the parts designed for different manufacturing technologies: the left one is designed for manufacturing by standard metalworking methods, and the shape of the right part is obtained by topological optimization for additive manufacturing $[1,7]$. The right-hand part with $28 \%$ less weight has lower maximum stresses and less deformation under load. 


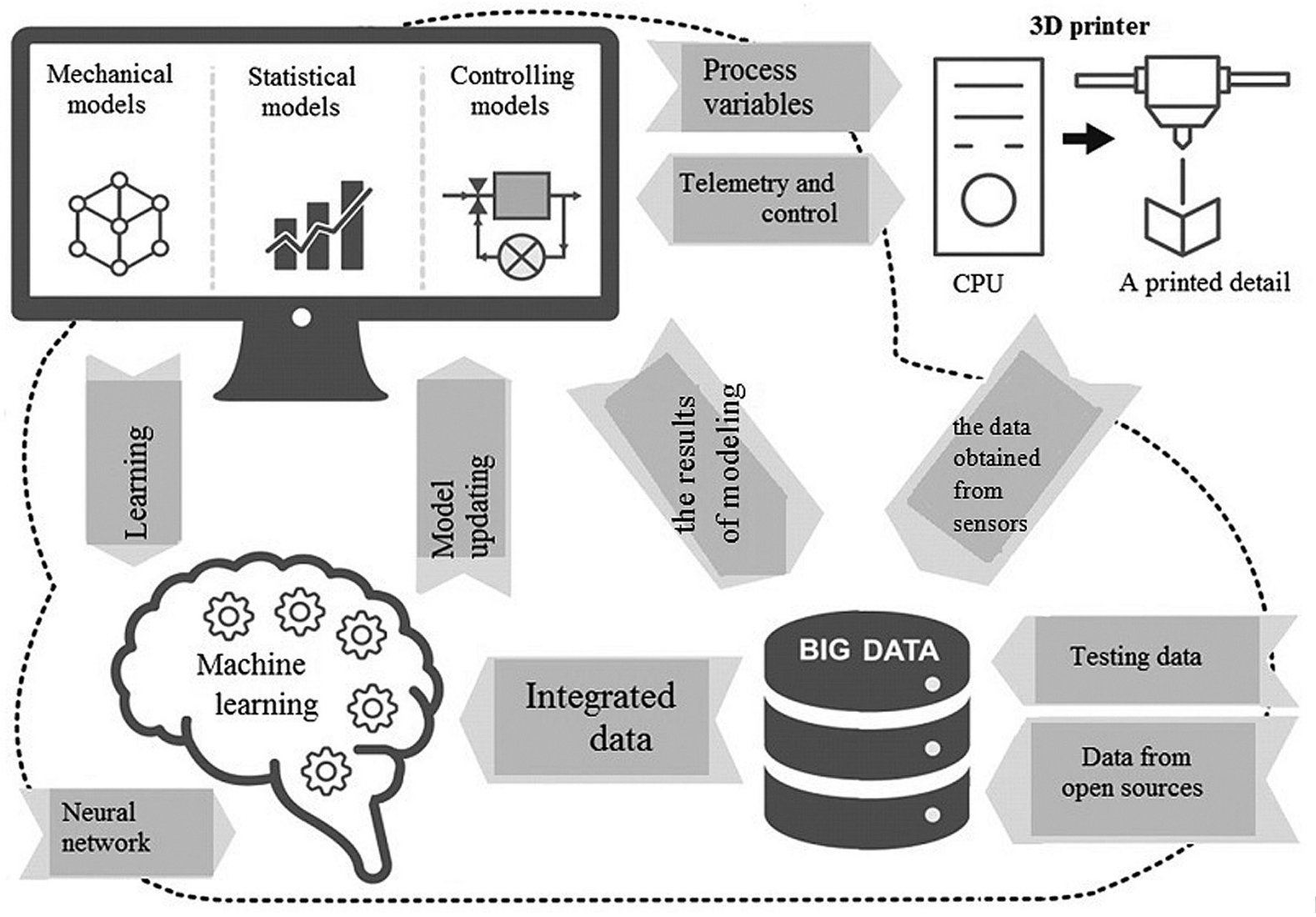

Fig. 3. Diagram of the DT in controlling the process of 3D-printing with metals [1]

Fig. 2 shows the results of redesigning a reflector bracket for additive manufacturing based on topological optimization (left - before, right - after), performed using the Integrated Computer Design and Engineering System (ICDES, a light version of the CML-Bench system) at the CompMechLab Engineering Center, St. Petersburg Polytechnic Institute [8]. This redesign succeeded to reduce the weight of the structure based on topological optimization by $43 \%$ compared to the original version. It can be seen that the structure with an optimized shape resembles the structures of living nature, where the material is "optimally" moved by natural evolution precisely to those zones where it "works" or "bears the load".

\section{Structural Design Approach}

In optimal designs (as well as in wildlife), there are no flat elements and profiles of constant thickness. In addition, topological optimization makes it possible to create lattice, cellular and foamy structures, which are also common in nature, for example, found in bone tissue. The regularity that the parts created by optimization methods (with mechanical strength at the minimum weight) resemble objects of wildlife led to the formation of the terms "bionic design" and "nature-like structures".

Bionic design is a related concept in relation to the concept of „generative design“ - an approach to design (detail, animation, image, etc.) in which a person delegates part of the processes to com- 


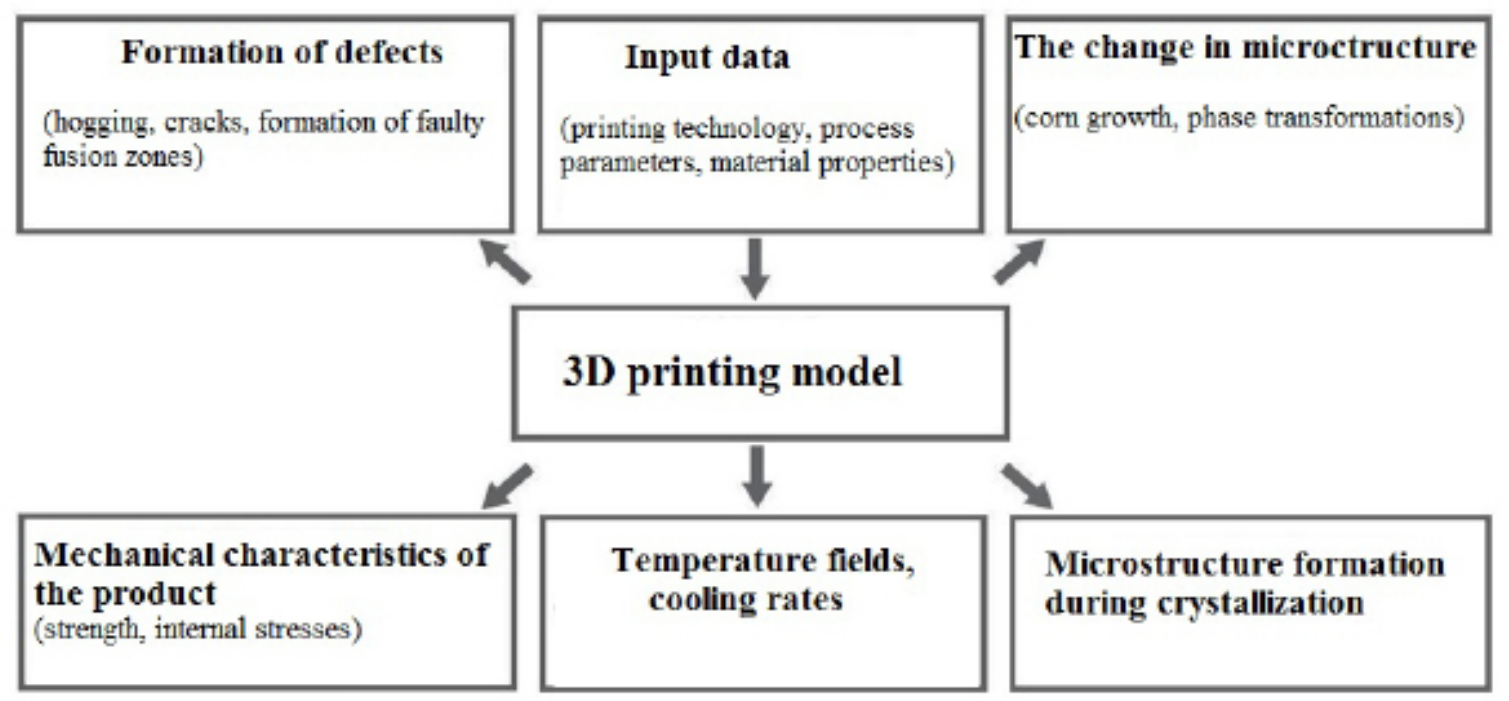

Fig. 4. Used models of 3D-printing of metal products [1]

puter platforms [1]. Generative design technology changes the nature of human interaction with the program. Thus it becomes an effective tool for the creative process. Some generative systems allow the user to reformulate, correct and refine the problem based on intermediate results, and also self-learn in the process of finding solutions. According to the interpretation of the specialists of the NTI St. Petersburg Polytechnic Institute Center and the CompMechLab Group of Companies, generative design is a part of bionic design, as the design and production of personalized products using computer engineering, optimization (multi-parameter, topological, multi-criteria, etc.) and advanced production technologies, primarily additive. Under these technologies the resulting structures are similar to those observed in nature [1].

The expanded interpretation of the term ,generative design" assumes that DT is a tool that uses generative design methods in the sense that the activity of a designer equipped with DT technology increasingly relies on the intellectual functions of development tools and the capability of multidimensional optimization of the structure for a set of specified targets and resource constraints.

\section{Advantage of Using Additive}

It is important to note that the possibility of using $3 \mathrm{D}$ printing is limited not only by the possibilities of creating a structure of a certain quality, but also by economic considerations. If by using additive technology to print the same element that was designed for non-additive technologies, then this solution will almost always be more expensive than the traditional one, since production on the basis of traditional CNC machines has already been optimized for the minimum cost. However, the more designing elements a designer involves for optimization, the more likely it is that the move to additive technology will be economically viable. In total, if we take several dozen elements that are connected using traditional technologies, including bolted, welded and other joints, then the same structure using additive technologies can be made not from 100 parts, but from 10, using much fewer components, which already leads to significant savings.

Then, it makes sense not to make an existing traditional part with the help of additive technologies, but to redesign the structure for additive technologies. Here the question already arises of a paradigm 
shift, of a transition to new design principles. An experienced designer during the design process keeps in mind the limitations of the equipment he got used to, automatically introducing design constraints. But in the case of additive manufacturing, many restrictions are removed, the form can be almost any, and, as a rule, it is beyond the intuition, experience and knowledge of the designer. And in the case of sufficiently large metal structures manufactured in the foundry, foundry workers and thermists are exposed to the same conditions.

If previously the temper in structures subjected to technological operations (casting, welding or heat treatment) were determined by calculation, today, using 3D-printing with metals, it is possible to solve the inverse problem - to set a favorable distribution of internal stresses during the printing process. Moreover, by controlling the parameters of the $3 \mathrm{D}$ printing process (for example, such as the cooling rate of the metal), it is possible to influence the formation of the microstructure during the crystallization of the metal, to influence the tendency to the formation of microdefects, cold and hot cracks.

Fundamentally new opportunities are emerging at the intersection of DT technologies, 3D printing and AI. Namely, the possibility to print a real object (the physical part of the twin) practically real-time according to the digital model (the virtual part of the twin) opens up. Also it is possible to analyze its properties with the help of sensors and correct these properties immediately [9]. All the elements of the DT are present in the Fig. 3. There are a mathematical model of the formation of a physical object (process model), a statistical model based on machine learning based on data received from sensors from a real physical object, and the physical object itself, formed in the process of $3 \mathrm{D}$ printing. And the most important thing is that in the process of printing, not only the desired shape of a physical object (metal structure) can be created, but also its internal structure with given operational properties and a field of internal stresses (Fig. 4).

The approaches that are used to create the DT of the $3 \mathrm{D}$ printing process with metals (Fig. 3) are based on modeling the effect of moving heat sour- ces (laser beam, electron beam, or electric arc) on the metals used for printing. The calculations take into account the analysis of temperature fields using the finite element method or other methods [2]. The microstructures formed in accordance with different rates of melt cooling are estimated by the way of calculation. The mode of deformation of the metal structure is numerically analyzed. Infrared cameras for remote temperature measurement are used as sensors. Acoustic emission control devices are used to assess the presence of internal defects.

\section{The Use of 4D And 5-D Printing Technologies in Production}

With the development of additive technologies, new possibilities for mathematical modeling and programming of the properties of future physical structures appear. Recently, new terms such as 4D and $5 \mathrm{D}$ printing have appeared. The method of 4D-printing assumes that the time as the fourth coordinate is added to the three ones, that is, the printed three-dimensional structure in the future may change in a special way under the influence of certain external factors [1]. Certain materials can change under the influence of water, heat, light, mechanical stress, and can be programmed for specific actions.

For example, researchers at MIT's SelfAssemblyLab are researching the creation of programmable materials that can be used in medical implants. In 5D printing technology (3D printing on a platform capable of swinging in two axes), using the same CAD model, a much stronger finished structure can be obtained if the method of applying the material changes in such a way that the deposited layers turn from smooth to tortuous [1]. Such technologies open up new possibilities for managing the physical part of the DT.

\section{Creation of Custom Designs}

Additive technologies are actively developing in Russia. In particular, in the engine industry there are companies that use $3 \mathrm{D}$ printing technology for the manufacture of individual parts. The enterpri- 


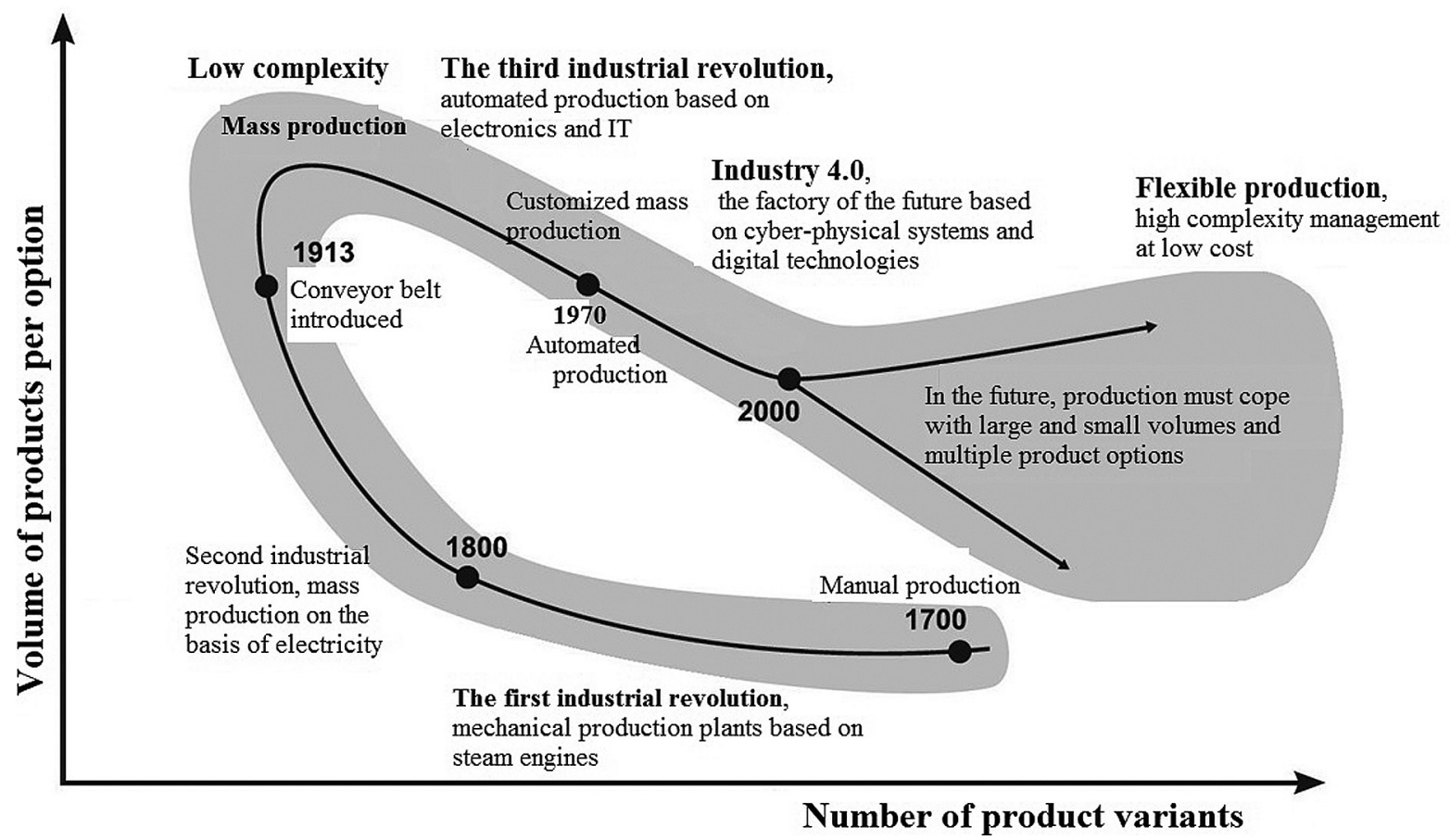

Fig. 5. Time (spiral) cycle of changes in the mass character and variability of manufactured products (structures) [1]

ses of the nuclear industry also begin to introduce 3D printing technologies in production. Additive technologies using the DT technology give a possibility to create a design according to individual requirements in a short time. Technologies develop in a spiral (Fig. 5), and in today's turn, developers are faced with the task of creating highly customized (custom-made) products (designs) in order to return to a new level of possibilities similar to handicraft production of individual products for each of the customers.

In the initial period of handicraft production (Fig. 5), the customization of goods was maximum (1700 on the curve), then the development proceeded in the direction of increasing the mass production and creating products "that are suitable for everyone." The maximum of the curve (based on the volume of products per design option) falls on the mass conveyor belt production of cars, the time when the famous phrase of Henry Ford was born: "The color of a car can be any, provided it is black."
Since the 60 s.of the last century, customization is growing. The number of models pre-configured to the preferences of small groups of consumers is increasing. In 2000, the curve approaches the embranchment: there is an increase in the complexity of mass goods, on the one hand, and an increase in product customization, on the other.

\section{Conclusion}

The importance of using DT for additive manufacturing is as follows. Customized fabrication of complex metal structures using 3D printing has been recognized as a potentially transformative tool for the healthcare, automotive and aerospace industries. However, after about a quarter of a century of research and development, only a few commercial alloys have been printed, and the market value of all 3D printed products now accounts for a fraction of the manufacturing economy [9]. This difficulty is explained by a significant variety of the structure 
and properties of printed metal products, as well as their susceptibility to defects. In addition, the current practice of evaluating metal products was carried out through lengthy trial and error using expensive printing equipment and raw materials. Although, neither the metal material that limits the $3 \mathrm{D}$ printing market niche, nor the high cost of production, nor the duration of product qualifications are critical factors. The creation of a DT for a 3D printing machine gave a possibility to reduce the amount of trial and error testing in order to achieve desired product characteristics and reduce the time required for qualifying a part to make additive metal products cost-effective. [9] has been shown that a complex DT of a $3 \mathrm{D}$ printing machine, consisting of mechanistic, control and statistical models of $3 \mathrm{D}$ printing, machine learning and big data, can reduce the volume of trial and error testing, reduce the number of defects and shorten the time between design and production.

We will summarize this review with the following paragraph. The collection of large amounts of data, the automation of production and the complication of mechanical engineering products contribute to the development of the DT technology. It is the result of a synergy between artificial intelligence, the Internet of Things and other solutions. The DT must virtually repeat the process of work in the finest details, with an accuracy of 5\%. Built-in sensors must update information in real time. A fullfledged CD allows not only to test hypotheses about the methods of constructing technological schemes of equipment, but also to conduct a virtual launch and adjustment of complexes before they are built, as they say, "live". A full-fledged CD allows not only to test hypotheses about the methods of constructing technological schemes of equipment, but also to conduct a virtual launch and adjustment of complexes before they are built, as they say, "live". This significantly reduces the implementation time and reduces the cost of correcting errors in design, including foundry processes, optimal design of castings and the use of additive technology for their production.

\section{REFERENCES}

1. Prokhorov, A., Lysachev, M., 2020. Tsifrovoy dvoynik. Analiz, trendy, mirovoy opyt. Izd. pervoye, ispravlennoye i dopolnennoye. M.: OOO «Al'yansPrint», 401 p. (In Russian).

2. Doroshenko, V.S., Kravchenko, V.P., 2020. "Yak concept of a digital two-wheel drive, you can use the theory and practice of life processes on the application of the model for gasification". Lityo Ukrainy, 10. (In Russian).

3. Doroshenko, V.S., 2014. "3D tekhnologii izgotovleniya otlivok kak primery additivnogo proizvodstva". Metall i litye Ukrainy, 12, pp. 4- 9. (In Russian).

4. Doroshenko, V.S., 2016. "Additivnoye proizvodstvo - rastushchaya otrasl' mirovoy promyshlennosti". Metall i litye Ukrainy, 5, pp. 3-44. (In Russian).

5. Doroshenko, V.S., 2015. “3D-tekhnologii dlya formovki i lit'ya”. Lit'ye i metallurgiya, 3, pp. 30-39. (In Russian).

6. Doroshenko, V.S., 2016. "Primery 3D-tekhnologii v liteynom proizvodstve". Snizheniye metalloyemkosti otlivok. Lit'ye i metallurgiya, 1, pp. 34-39. (In Russian).

7. Chekhovich, A., Topologicheskaya optimizatsiya geometrii izdeliya kak put' povysheniya pribyl'nosti predpriyatiya. [online] Available at: <https://blog.iqb.ru/geometry-topology-optimization/> [Accessed 22 Aug. 2020] (In Russian).

8. Pereproyektirovaniye kronshteyna reflektora na osnove topologicheskoy optimizatsii s primeneniyem ISKPI. [online] Available at: <http://fea.ru/project/199> [Accessed 22 Aug. 2020] (In Russian).

9. Mukherjee, T., DebRoy, T. A digital twin for rapid qualification of $3 \mathrm{D}$ printed metallic components. [online] Available at: <https://www.sciencedirect.com/science/article/abs/pii/S2352940718304931?via\%3Dihub>[Accessed 22 Aug. 2020].

Received 20.08.2020 


\section{ЛІТЕРАТУРА}

1. Прохоров А., Лысачев М. Научн. ред. Боровков А. Цифровой двойник. Анализ, тренды, мировой опыт. Изд. первое, исправленное и дополненное. М.: ООО «АльянсПринт», 2020. 401 с.

2. Дорошенко В. С., Кравченко В. П. Як концепція цифрового двійника зможе осучаснити теорію і практику ливарних процесів на прикладі лиття за моделями, що газифікуються. Литьё Украины, 2020. №10. С. 17-25.

3. Дорошенко В.С. 3D технологии изготовления отливок как примеры аддитивного производства. Металл и литье Украины. 2014. № 12. С. 4- 9.

4. Дорошенко В.С. Аддитивное производство - растущая отрасль мировой промышленности. Металл и литье Украины. 2016. №. 5. C. 3-44.

5. Дорошенко В.С. 3D-технологии для формовки и литья. Литье и металлургия. 2015. № 3. C. $30-39$.

6. Дорошенко В.С. Примеры 3D-технологии в литейном производстве. Снижение металлоемкости отливок. Литье и металлургия. 2016. № 1. С. 34-39.

7. Чехович A. Топологическая оптимизация геометрии изделия как путь повышения прибыльности предприятия. URL: https://blog.iqb.ru/geometry-topology-optimization/

8. Перепроектирование кронштейна рефлектора на основе топологической оптимизации с применением ИСКПИ. URL: http://fea.ru/project/199

9. Mukherjee T., DebRoy T. A. digital twin for rapid qualification of 3D printed metallic components. URL: https://www.sciencedirect.com/science/article/abs/pii/S2352940718304931?via\%3Dihub

Надійшла 20.08.2020 
B.C. Дорошенко, доктор техн. наук, старший наук. співробітник.,

Фізико-технологічний інститут металів та сплавів (ФТІМС) НАН України, 03680, м. Київ, бульвар Вернадського, 34/1,Україна, doro55v@gmail.com

O.В.Токова, молодший наук. співробітник, Міжнародний науково-навчальний центр інформаційних технологій та систем НАН та МОН України, просп. Глушкова, 40, Київ 03187, Україна, len327@ukr.net

\section{ЦИФРОВИЙ ДВІЙНИК І ОПТИМІЗАЦІЯ ЛИТИХ МЕТАЛОКОНСТРУКЦЙ ПРИ АДИТИВНОМУ ВИРОБНИЦТВІ}

Вступ. Актуальним завданням інженерної науки є співпраця технологічного розвитку національної економіки, модернізація ії матеріальних та технічних баз переробної промисловості. Зростання складності продукції машинобудування міняє стратегію іiї виробництва. Оптимізація тисяч параметрів для створення конкурентоспроможних виробів сьогодні практично неможлива без використання технології цифрових двійників (ЦД), хоча сама технологія ЦД, зокрема в ливарно-металургійній галузі, все ще знаходиться на ранній стадії розвитку. Якщо для забезпечення надійності й безпеки машин і механізмів та їхніх литих конструкцій необхідно значне збільшення числа випробувань, то їх швидше і дешевше робити у віртуальному просторі на стадії проектування, ніж на більш пізній стадії в металі. В огляді розглянуто деякі приклади застосування технології ЦД для проектування ливарних металевих заготовок, оптимізації їхніх конструкцій при виготовленні адитивним методом.

Метою статті є проведення огляду технологій ЦД та розробка пропозицій застосування технологій ЦД для оптимізації литих металоконструкцій при адитивному виробництві.

Результати. Одним із сучасних технологічних трендів є «цифровізація» процесів виробництва, особливості якої для отримання литих металоконструкцій аддитивними методами розглядаються в статті. Виконано огляд поняття ЦД, розглянуто які технології розкривають це поняття, а також як застосування ЦД впливає на розвиток адитивного виробництва металовиробів. Для конструювання металопродукції відзначено такі поняття, як «біонічний дизайн» та «генеративний дизайн», які змінюють характер взаємодії людини з програмою, що стає ефективним інструментом творчого процесу. Показано приклади комп'ютерного інжинірингу при топологічній оптимізації конструкцій металевих заготовок.

Висновки. Огляд ряду джерел інформації показує, що серед передових технологій ЦД є інтегратором практично всіх «наскрізних» цифрових технологій та виступає драйвером, що дає передумови розвитку і дозволяє підприємствам й цілим галузям переходити на рівень сталого розвитку. Технологія ЦД має великі перспективи, оскільки є необхідною не лише для створення і експлуатації сучасного «розумного» продукту, але й для його регулярної підтримки, оновлення та постійної адаптації до нових вимог й умов з перенесення накопичених даних і методів для створення нових машин, конструкцій та матеріалів.

Ключові слова: иифровий двійник, моделювання, оптимізація, адитивне виробництво, металоконструкція, технологія Зр-друку. 